\title{
Flow of Hydrolysed Polyacrylamide Mother Liquor through Filter Bag: Detecting the Effects of Formulation and Process Properties on Pressure Drop
}

\author{
Z.-M. Feng, ${ }^{*}$ X. Fang, and H.-H. Ding \\ School of Mechanical Science and Engineering, Northeast Petroleum University, \\ 163318 Daqing, P.R. China
}

\begin{abstract}
|| Abstract
Hydrolysed polyacrylamide (HPAM) mother liquor is mainly used to extract oil. The HPAM solution is needed to filter the impurity using a bag filter before it is injected into the oil well. Therefore, the pressure drop of HPAM mother liquor must be less than 0.02 MPa in the processing of impurity filtration. The influence factors on pressure drop need to be researched. In this work, the computational fluid dynamics program (CFD) was used to research some key influence factors on pressure drop, such as porosity, outlet pressure of filter, inlet flow rate and viscosity of mother liquor. The simulation results indicated that with increasing porosity, outlet pressure, inlet flow rate and mother liquor viscosity, the pressure drop had increased after flowing through the filter bag.
\end{abstract}

\section{\| Keywords}

Hydrolysed polyacrylamide mother liquor, filter bag, pressure drop, porosity, viscosity

\section{Introduction}

The application of HPAM first started in the water treatment field, such as raw water treatment, wastewater treatment, industrial water treatment and urban wastewater treatment. ${ }^{1}$ In recent years, HPAM has been applied on the large-scale in oil field production. ${ }^{2-3}$ Concentration and dosage of the polymer was related to raw oil recovery efficiency. ${ }^{4-5}$ At a certain degree, with an increase in polymer concentration and liquor viscosity, the oil displacement efficiency was better. However, at the same flow rate, the flow concentration was greater, the probability of blocking the hole with the polymer particle was greater, and the rise in pressure drop was quicker. ${ }^{6}$ At present, our oil field production has already injected HPAM-water solution to improve flow rate between oil and water, and improved the petroleum content of produced fluid. ${ }^{7-8}$

Many researchers have used the CFD software to simulate and design the bag filter to replace the test for cost and time cutting. H. Gao and L. J. GuO ${ }^{9}$ used CFD software (Fluent 5.0) to optimize a bag filter dust collector by application of the k- $\varepsilon$ model. They found that the pressure field of optimized bag filter is quite uniform and its total pressure loss through the bag house is reduced by about $60 \%$ in relation to the prototype bag filter. Li et al. ${ }^{10}$ used CFD program to simulate the unit flow distribution of bag filter and drew the distribution graph of filtering velocity along the height direction and the distribution characteristics of flow lifting speed between bags at different heights, thus offering theoretical evidence for improvement and design of bag filter. $X$. L. Zhang et al. ${ }^{11}$ used CFD to simulate the main structur-

* Corresponding author: Dr. Feng Zi-Ming

e-mail: xueyuanfzm@163.com al parameters of intake uniform board for the airflow distribution in bag filter with orthogonal tests. They found that the impact factors on airflow uniformity are board length, angle, number of boards, height, and increasing length. L. X. Ge et al. ${ }^{12}$ used CFD software Fluent 6.3 to simulate the flow field in a bag filter and analysed the internal velocity flow field and pressure distribution. The CFD program can be used to simulate the inter flow field of pressure, velocity and temperature and so on, and can optimize the bag filter. Therefore, in this work we also used the CFD program to study the influence factors on pressure drop of bag filter.

CFD has developed very quickly in the past 20 years, because not only did the development of the computer hardware industry provide the massy material basis, but the theoretical analysis or the experimental method also had limitations. Thus, the analytical solution was not achieved due to the complexity of the question, or the test was not conducted because it was expensive. However, CFD was low cost, and capable of treating complex questions. CFD software can save the science researcher a lot of time, which he could put to good use on the study of physical problems. Therefore, in this work we selected the CFD software to simulate the flow field of the bag filter.

Before the HPAM mother liquor is injected into the oil well, the impurity must be leached by filter bag, so the permeability of the filter bag will change with time. Therefore, we used the CFD program to numerically simulate the inner flow field of the filter, and studied the influence of filter bag porosity, outlet pressure, inlet flow rate and mother liquor viscosity on the flow field and pressure drop, in order to provide a reference for the estimation of pressure drop and change period of the filter bag. 


\section{Simulation model and numerical method}

The filter bag is shown in Fig. 1. The flow media in the filter was HPAM mother liquor. Medium density was $1010 \mathrm{~kg} \mathrm{~m}^{-3}$, mass fraction $0.15 \%$, working temperature $40{ }^{\circ} \mathrm{C}$, outlet pressure $3.5 \mathrm{MPa}$, maximum flow $150 \mathrm{~m}^{3} \mathrm{~h}^{-1}$.

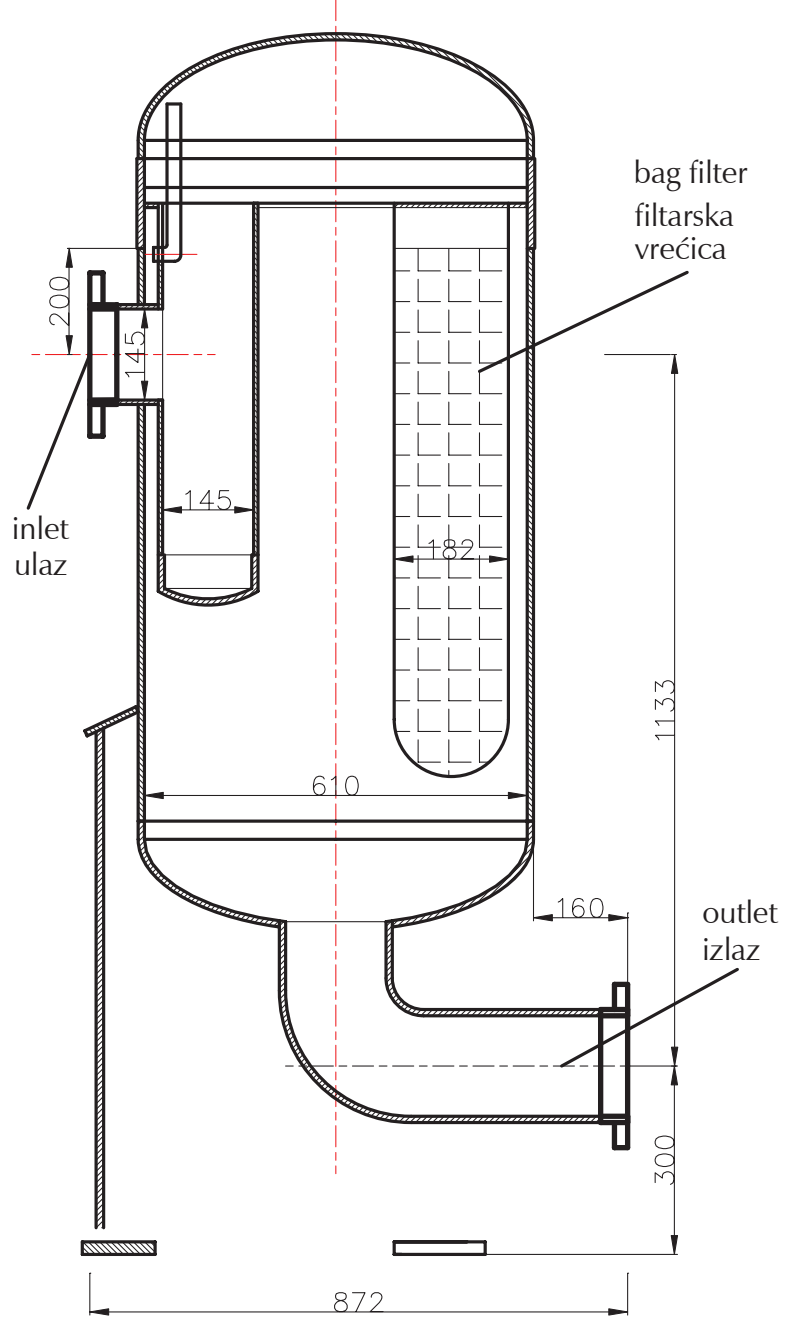

Fig. 1 - Filter bags

Slika 1 - Filtarske vrećice

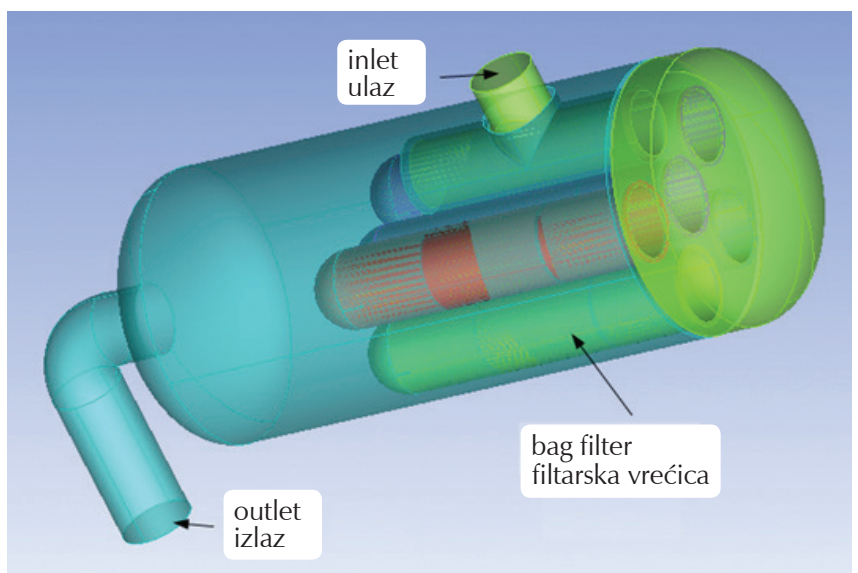

Fig. 2 - Three-dimensional perspective of filter Slika 2 - Filtar
Fig. 2 is the three-dimensional geometrical model of the filter; inlet and outlet diameters are $160 \mathrm{~mm}$, vessel diameter is $610 \mathrm{~mm}$, vessel height is $1260 \mathrm{~mm}$. The length, diameter and thickness of the filter bag are respectively $820 \mathrm{~mm}, 160 \mathrm{~mm}, 2.8 \mathrm{~mm}$. The geometrical model is a single vessel with five filter bags. The green section is the inlet fluid domain, the cyan section is the outlet fluid domain, the five thin-wall constructions are filter bags. The filter bags are assumed to be porous media at the numerical simulation processing.

The grid information of the filter are statistic as follows; inlet grid is 2.236 million, outlet grid is 1.395 million, filter bag grid total number is 1.397 million. The filter mesh was generated by ANSYS-ICEM software, the self-adaption tetrahedral mesh occupied the main section, and the mesh of the filter bag domain was denser than other mesh and all the wall surfaces of the filter have a boundary layer mesh.

Mesh quality is displayed as a histogram where the abscissa ( $x$-axis) displays the element quality on a scale from 0 (worst) to 1 (best), and the ordinate (y-axis) displays the number of elements in each quality range. The default is 20 bars or divisions between 0 and 1. Thus, the first bar would display the number of elements whose quality is between 0 and 0.05 , and the next bar between 0.05 and 0.1 . Mesh quality of the bag filter is shown in Fig. $3 \mathrm{~d}$. The lowest quality coefficient is 0.4 that completely satisfies the demand for mesh quality by CFD software CFX.

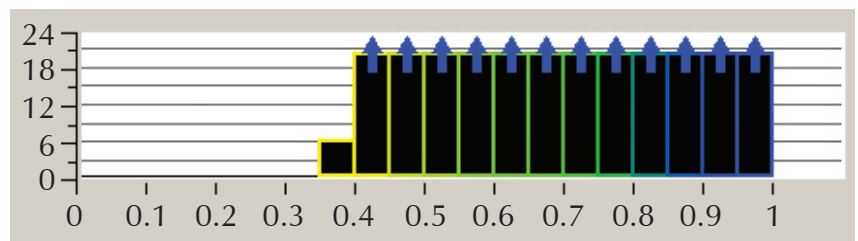

Fig. 3 - Grid quality information Slika 3 - Kvaliteta rešetke

The total designed computable cases were 20 by changing porosity, inlet flow rate, outlet pressure and medium viscosity. The boundary conditions were as follows: inlet condition was velocity, outlet condition was static pressure, wall condition was thermal isolation and no slip. The inlet part and outlet part of the filter were defined as the fluid domain, the filter bags construction were defined as porous medium. The turbulence model was $k-\varepsilon$ model, the disperse method of governing equation was finite volume method, difference scheme was second order upwind scheme, the pressure and velocity coupling was SIMPLE algorithm.

The turbulence energy $k$ and its turbulent dissipation $\varepsilon$ in the standard $k-\varepsilon$ model could be achieved by the following transport equation.

$$
\begin{aligned}
\frac{\partial}{\partial t}(\rho k)+\frac{\partial}{\partial x_{i}}\left(\rho k u_{i}\right)= & \frac{\partial}{\partial x_{j}}\left[\left(\mu+\frac{\mu_{\mathrm{t}}}{\sigma_{k}}\right) \frac{\partial k}{\partial x_{j}}\right]+ \\
& +G_{k}+G_{b}-\rho \varepsilon-Y_{M}+S_{k}
\end{aligned}
$$




$$
\begin{aligned}
\frac{\partial}{\partial t}(\rho \varepsilon)+\frac{\partial}{\partial x_{i}}\left(\rho \varepsilon u_{i}\right)= & \frac{\partial}{\partial x_{j}}\left[\left(\mu+\frac{\mu_{t}}{\sigma_{\varepsilon}}\right) \frac{\partial \varepsilon}{\partial x_{j}}\right]+ \\
& +C_{1 \varepsilon} \frac{\varepsilon}{k}\left(G_{k}+C_{3 \varepsilon} G_{b}\right)-C_{2 \varepsilon} \rho \frac{\varepsilon^{2}}{k}+S_{\varepsilon}
\end{aligned}
$$

Computational expression of turbulence viscosity $\mu_{\mathrm{t}}$ was as follows:

$$
\mu_{\mathrm{t}}=\rho C_{\mu} \frac{k^{2}}{\varepsilon}
$$

Model constants are as follows: $C_{1 \varepsilon}=1.44, C_{2 \varepsilon}=1.92$, $C_{\mu}=0.09, \sigma_{k}=1.0, \sigma_{\varepsilon}=1.3$.

\begin{tabular}{|c|c|}
\hline $\begin{array}{l}\text { Option } \\
\text { Opcija }\end{array}$ & $\begin{array}{l}\text { Content } \\
\text { Sadržaj }\end{array}$ \\
\hline $\begin{array}{l}\text { reference pressure } \\
\text { referentni tlak }\end{array}$ & $0.1 \mathrm{MPa}$ \\
\hline $\begin{array}{l}\text { buoyancy model } \\
\text { model uzgona }\end{array}$ & $\begin{array}{l}\text { non-buoyant } \\
\text { neplutajući }\end{array}$ \\
\hline $\begin{array}{l}\text { domain motion } \\
\text { kretanje domene }\end{array}$ & $\begin{array}{c}\text { stationary } \\
\text { stacionarno }\end{array}$ \\
\hline $\begin{array}{l}\text { heat transfer } \\
\text { prijenos topline }\end{array}$ & $\begin{array}{l}\text { isothermal } \\
\text { izotermno }\end{array}$ \\
\hline $\begin{array}{l}\text { fluid temperature } \\
\text { temperatura tekućine }\end{array}$ & $40^{\circ} \mathrm{C}$ \\
\hline $\begin{array}{l}\text { turbulence model } \\
\text { model turbulencije }\end{array}$ & $k-\varepsilon$ \\
\hline $\begin{array}{l}\text { turbulence intensity } \\
\text { intenzitet turbulencije }\end{array}$ & $5 \%$ \\
\hline $\begin{array}{l}\text { porous loss model } \\
\text { model gubitka poroznošću }\end{array}$ & $\begin{array}{l}\text { isotropic loss } \\
\text { izotropni gubitak }\end{array}$ \\
\hline $\begin{array}{l}\text { residual type } \\
\text { vrsta ostatka }\end{array}$ & RMS \\
\hline $\begin{array}{l}\text { residual target } \\
\text { temeljni kriterij }\end{array}$ & $1.0 \cdot 10^{-4}$ \\
\hline
\end{tabular}

Table 1 - Basic input parameters

Tablica 1 - Osnovni ulazni parametri

\section{Results and discussion}

Fig. 4 shows the three-dimensional streamline and Fig. 5 presents the three-dimensional velocity vector in the filter. These figures indicated that the flow was three-dimensional, in the inlet pipe and the outlet pipe the flow rates were faster than in other places. HPAM mother liquor evenly flowed into the five filter bags. At the inlet position of the filter bag, the flow suddenly accelerated where there was more flow loss than in other places. In addition, the flow loss was mainly made up of boundary flow loss, secondary flow loss and other inner fluid friction.

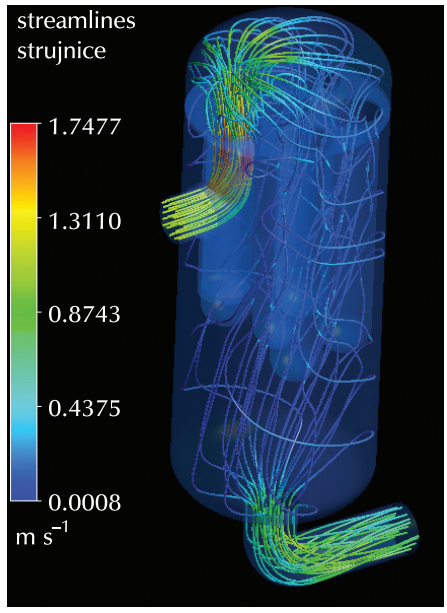

Fig. 4 - Three-dimensional streamline

Slika 4- Trodimenzionalni prikaz Slika 5-Trodimenzionalni strujnica

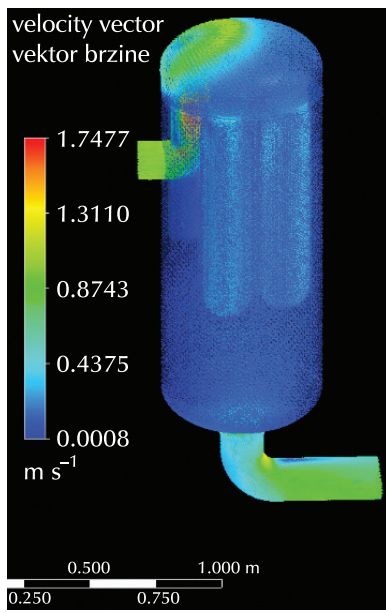

Fig. 5 - Three-dimensional velocity vector vektori brzine

\section{Influence of porosity on pressure drop}

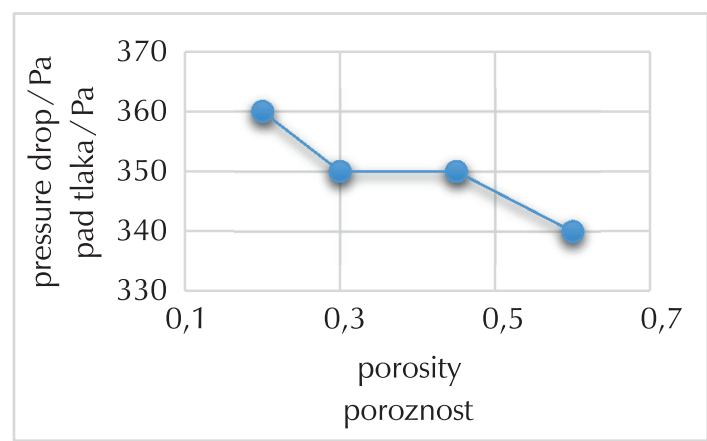

Fig. 6 - Correlation curve between porosity and pressure drop Slika 6 - Korelacijska krivulja između poroznosti i pada tlaka

The total porosity of the bag filter is the ratio of total pore space volume of the bag filter and the total volume of the filter bag, and is indicated by percentage. Larger total porosity of the bag filter indicates that the bag filter has larger pore space. When the bag filter is used for a certain amount of time, some particles will block the pore space thus resulting in low porosity. Therefore, it is necessary to study the influence of porosity on the pressure drop. As shown in Fig. 6, with increasing porosity from 0.2 to 0.6 , the pressure drop decreased from $3.6 \cdot 10^{-4} \mathrm{MPa}$ to $3.4 \cdot 10^{-4} \mathrm{MPa}$. In terms of increasing amplitude, the total pressure drop was not significant and kept at about $3.5 \cdot 10^{-4} \mathrm{MPa}$. It was indicated that the smaller the porosity, the greater the resistance of flow, and the total pressure drop computed by CFD technology could reflect the pressure change rule in the filter in a wide scope of porosity. 
Influence of outlet pressure on pressure drop

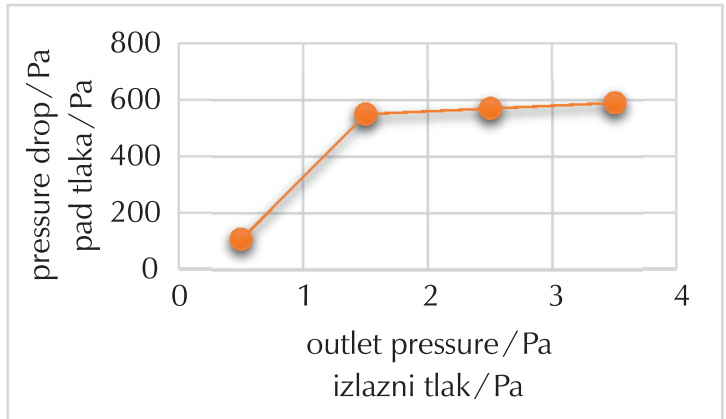

Fig. 7 - Correlation between outlet pressure and pressure drop Slika 7 - Odnos između izlaznog tlaka i pada tlaka

When outlet pressure of the bag filter increased, the flow resistance of the solution increased, the solution needed more energy to overcome resistance. Therefore, the pressure drop of the bag filter will increase with the increase in outlet pressure. The influence rule of filter outlet pressure on pressure drop could be observed in Fig. 7. With the increase in outlet pressure from 0.5 MPa to 1.5 MPa, the pressure drop increased, but with outlet pressure from 1.5 $\mathrm{MPa}$ to $3.5 \mathrm{MPa}$, the pressure drop kept stable at near $5.8 \cdot 10^{-4} \mathrm{MPa}$.

\section{Influence of inlet flow rate on pressure drop}

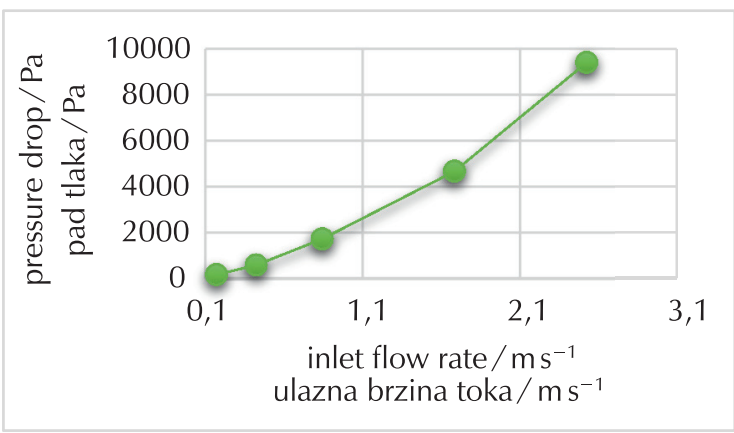

Fig. 8 - Correlation curve between inlet flow rate and pressure drop

Slika 8 - Korelacijska krivulja između ulaznog protoka i pada tlaka

As shown in Fig. 8, with the inlet flow rate increasing from $0.1 \mathrm{~m} \mathrm{~s}^{-1}$ to $2.6 \mathrm{~m} \mathrm{~s}^{-1}$, the pressure drop rapidly increased, the dependency of the two was non-linear with large increasing amplitude value, the pressure drop ranged from $1.7 \cdot 10^{-4} \mathrm{MPa}$ to $1 \cdot 10^{-2} \mathrm{MPa}$ that stepped over two orders of magnitude. The flow resistance in the filter was made of frictional drag and local resistance. The frictional drag was generated by internal friction of flow when flowing through the filter, thus it is also named one-way resistance. Local resistance was mainly induced by the bag filter. The two resistances increased with the increase in inlet velocity.

\section{Influence of viscosity on pressure drop}

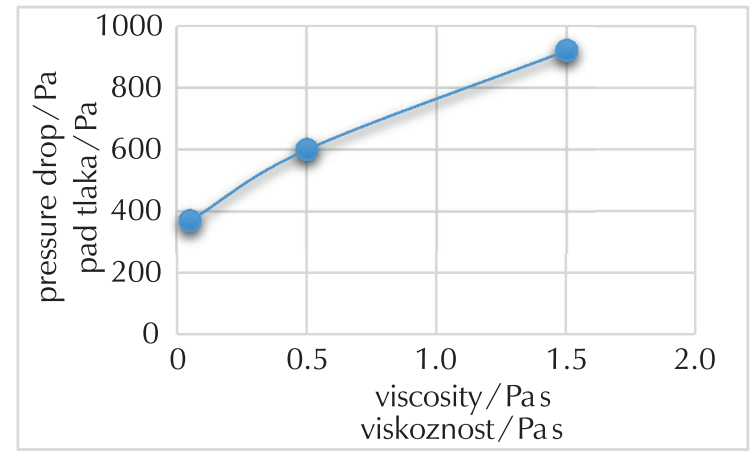

Fig. 9 - Correlation between viscosity and pressure drop Slika 9 - Odnos između viskoznosti i pada tlaka

AN913, AN923, AN934 are three different types of HPAM products all produced by SNF, France. ${ }^{13}$ These three types of HPAM come in the form of powder and granules, and their relative molecular masses are $1.17 \cdot 10^{7}$, $1.19 \cdot 10^{7}, 2.11 \cdot 10^{7}$, respectively. The initial viscosity of AN913, AN923, and AN934 were $16.12 \cdot 10^{-3}$ Pa s, $21.11 \cdot 10^{-3}$ Pa s, $28.14 \cdot 10^{-3}$ Pas, respectively. The viscosity of HPAM solution increased with the increase in temperature.

As shown in Fig. 9, as the viscosity increased, the pressure drop increased. The total pressure-drop curve increased approximately linearly with direct proportion. At viscosities of AN913 solution, AN923 solution, AN934 solution of $50 \mathrm{cP}\left(5.0 \cdot 10^{-2} \mathrm{Pas}\right), 100 \mathrm{cP}\left(1.00 \cdot 10^{-1} \mathrm{~Pa} \mathrm{~s}\right), 250 \mathrm{cP}$ $\left(2.50 \cdot 10^{-1} \mathrm{~Pa} \mathrm{~s}\right)$, respectively, the pressure drops were $3.7 \cdot 10^{-4} \mathrm{MPa}, 4.1 \cdot 10^{-4} \mathrm{MPa}, 4.9 \cdot 10^{-4} \mathrm{MPa}$, respectively. Fluid resistance is proportional to the viscosity, because the internal resistance in the main flow and in the boundary layer will increase with the increase in flow viscidity. This is the main cause of the increased pressure drop in the bag filter.

\section{Conclusion}

The physical model of a filter bag was simplified as porosity material, and the CFD simulation model of filter was built. Conducted was the numerical computation of influence factors on pressure drop, such as porosity, outlet pressure, inlet flow rate and viscosity.

1) The total pressure loss, calculated by CFD software, can reflect the pressure drop changing rule in the filter.

2) With the porosity increasing, the pressure drop slightly decreased. But overall, the total pressure drop was not significant and kept at about 3.6 $10^{-4} \mathrm{MPa}$.

3) When the outlet pressure was in the scope of $0.5 \mathrm{MPa}$ to $1.5 \mathrm{MPa}$, the pressure drop increased quickly from $1 \cdot 10^{-2} \mathrm{MPa}$ to $5.5 \cdot 10^{-4} \mathrm{MPa}$. When the outlet pressure ranged from 1.5 $\mathrm{MPa}$ to $3.5 \mathrm{MPa}$, the pressure drop nearly kept stable, at about $5.8 \cdot 10^{-4} \mathrm{MPa}$. 
4) With the inlet flow rate increasing from $0.1 \mathrm{~m} \mathrm{~s}^{-1}$ to $2.6 \mathrm{~m} \mathrm{~s}^{-1}$, the pressure drop rapidly increased, the dependency of the two was non-linear with large increase in amplitude value, the pressure drop ranged from $1.7 \cdot 10^{-4} \mathrm{MPa}$ to $1 \cdot 10^{-2} \mathrm{MPa}$ that stepped over two orders of magnitude.

5) As viscosity increased, the pressure drop increased. The total pressure-drop curve increased approximately linearly with direct proportion. When the viscosities were $50 \mathrm{CP}\left(5.0 \cdot 10^{-2} \mathrm{~Pa} \mathrm{~s}\right), 495 \mathrm{cP}\left(4.95 \cdot 10^{-1} \mathrm{~Pa} \mathrm{~s}\right), 1500 \mathrm{cP}$ (1.500 Pa s), the pressure drops were $3.7 \cdot 10^{-4} \mathrm{MPa}$, $6 \cdot 10^{-4} \mathrm{MPa}, 9.2 \cdot 10^{-4} \mathrm{MPa}$, respectively.

\section{List of abbreviations and symbols Popis kratica i simbola}

\begin{tabular}{|c|c|}
\hline CFD & $\begin{array}{l}\text { - computational fluid dynamics } \\
\text { - računalna dinamika fluida }\end{array}$ \\
\hline HPAM & $\begin{array}{l}\text { - hydrolysed polyacrylamide } \\
\text { - hidrolizirani poliakrilamid }\end{array}$ \\
\hline RMS & $\begin{array}{l}\text { - root mean square } \\
\text { - korijen srednjeg kvadratnog odstupanja }\end{array}$ \\
\hline \multicolumn{2}{|c|}{$\begin{aligned} C_{1 \varepsilon \prime} C_{2 \varepsilon \prime} C_{3 \varepsilon \prime} C_{\mu}-\text { constants } & \\
& - \text { konstante }\end{aligned}$} \\
\hline$G_{b}$ & $\begin{array}{l}\text { - turbulence kinetic energy generated by } \\
\text { buoyancy, } \mathrm{J} \mathrm{m}^{-3} \mathrm{~s}^{-1} \\
\text { - turbulencijska kinetička energija uzrokovan } \\
\text { uzgonom, } \mathrm{J} \mathrm{m}^{-3} \mathrm{~s}^{-1}\end{array}$ \\
\hline$G_{k}$ & $\begin{array}{l}\text { - turbulence kinetic energy generated by laminar } \\
\text { velocity gradient, } \mathrm{J} \mathrm{m}^{-3} \mathrm{~s}^{-1} \\
\text { - turbulencijska kinetička energija uzrokovana } \\
\text { gradijentom laminarne brzine, } \mathrm{J} \mathrm{m}^{-3} \mathrm{~s}^{-1}\end{array}$ \\
\hline k & $\begin{array}{l}\text { - turbulence kinetic energy, } \mathrm{J} \mathrm{kg}^{-1} \\
\text { - turbulencijska kinetička energija, } \mathrm{J} \mathrm{kg}^{-1}\end{array}$ \\
\hline$S_{k}, S_{\varepsilon}$ & $\begin{array}{l}\text { - defined by users, } \mathrm{J} \mathrm{m}^{-3} \mathrm{~s}^{-1} \\
\text { - definirano od strane korisnika, } \mathrm{J} \mathrm{m}^{-3} \mathrm{~s}^{-1}\end{array}$ \\
\hline$t$ & $\begin{array}{l}\text { - time, s } \\
\text { - vrijeme, s }\end{array}$ \\
\hline$u_{i}$ & $\begin{array}{l}\text { - velocity, } \mathrm{m} \mathrm{s}^{-1} \\
\text { - brzina, } \mathrm{m} \mathrm{s}^{-1}\end{array}$ \\
\hline$Y_{M}$ & $\begin{array}{l}\text { - contribution of the fluctuating dilatation in } \\
\text { compressible turbulence, } \mathrm{J} \mathrm{m}^{-3} \mathrm{~s}^{-1} \\
\text { - doprinos fluktuirajuće dilatacije kompresibilne } \\
\text { turbulencije, } \mathrm{J} \mathrm{m}^{-3} \mathrm{~s}^{-1}\end{array}$ \\
\hline$\varepsilon$ & $\begin{array}{l}\text { - turbulence dissipation, } \mathrm{J} \mathrm{kg}^{-1} \mathrm{~s}^{-1} \\
\text { - turbulencijska disiipacija, J } \mathrm{kg}^{-1} \mathrm{~s}^{-1}\end{array}$ \\
\hline$\mu$ & $\begin{array}{l}\text { - dynamic viscosity, Pa s, P (1 P = 0,1 Pa s) } \\
\text { - dinamička viskoznost, Pa s, P }\end{array}$ \\
\hline$\mu_{\mathrm{t}}$ & $\begin{array}{l}\text { - turbulence viscosity, Pas, P (1 P = 0,1 Pa s) } \\
\text { - turbulencijska viskoznost, Pa s, P }\end{array}$ \\
\hline$\rho$ & $\begin{array}{l}\text { - density, } \mathrm{kg} \mathrm{m}^{-3} \\
\text { - gustoća, } \mathrm{kg} \mathrm{m}^{-3}\end{array}$ \\
\hline$\sigma_{k} \sigma_{\varepsilon}$ & $\begin{array}{l}\text { - turbulence Prandtl numbers for } k \text { and } \varepsilon \\
\text { - turbulencijski Prandtlov broj za } k \mathrm{i} \varepsilon\end{array}$ \\
\hline
\end{tabular}

\section{References \\ Literatura}

1. Y. C. Zhang, S.Q. Liu, B. Y. Gao, Development and prospects of cationic polyacrylamide for wastewater treatment, Ind. Water Treat. 22 (2002) 15-17, doi: http://dx.doi. org/10.3969/j.issn.1005-829X.2002.07.005.

2. Q. L. Gang, A dissertation on Chinese tertiary recovery technology, Oil Gas Recovery Techn. 5 (1998) 1-7, doi: http:// lib.cqvip.com/qk/90849X/199804/3208657.html.

3. P. H. Li, Z.M. Li, B. F. Li, Study on effect of polymer concentration on enhancing oil recovery and field test, Adv. Fine Petrochem. 10 (2009) 6-8, doi: http://dx.doi.org/10.3969/j. issn.1009-8348.2009.08.002.

4. Y. Liu, C. Z. Liu, F. L. Yang, Study on improving oil recovery using high concentration polymer solution, Oil Drill. Prod. Techn. 28 (2006) 33-35, doi: http://dx.doi.org/10.3969/j. issn.1000-7393.2006.04.011.

5. Q. M. Wang, G. Z. Liao, The practice and understanding of polymer flooding technology, Petrol. Geol. Oil Field Develop. Daqing 18 (1999) 1-5, doi: http://dx.doi.org/10.3969/j. issn.1000-3754.1999.04.001.

6. K. C. Taylor, R. A. Burke, Development of a flow injection analysis method for the determination of acrylamide copolymers in brines, J. Pet. Sci. Eng. 21 (1998) 129-139, doi: http://dx.doi.org/10.1016/S0920-4105(98)00042-4.

7. D. Wu, S. X. Guan, Y. G. Tai, Factors affecting the replacement of filter-bag for polypropylene amine liquor, Chem. Res. 4 (2011) 84-88. doi: http://dx.doi.org/10.3969/j.issn.10081011.2011.04.019.

8. D. Wu, S. X. Guan, Y. N. Tai, F. L. Meng, C. H. Song, Factors affecting the replacement period of filter-bag for polypropylene amine liquor, Chem. Res. 4 (2011) 84-88, doi: http:// dx.doi.org/10.3969/j.issn.1008-1011.2011.04.019.

9. H. Gao, L. J. Guo, Characteristics of Gas-Solid TwoPhase Flow for Filter Dust Collector with Low Entry, Journal of Xi-An JiaoTong University 34 (2000) 50-54, doi: http://dx.chinadoi.cn/10.3321\%2fj.issn\%3a0253987X.2000.05.012.

10. M. M. Li, F. T. Xing, Z. F. Chen, Numerical Simulation Analysis on Bag Filter Flow Filed Based on CFD, Ind. Safety Environ. Prot. 37 (2011) 19-21, doi: http://dx.chinadoi. cn/10.3969\%2fj.issn.1001-425X.2011.01.008.

11. X. L. Zhang, H. G. Shen, R. Zhou, Z. Liang, J. S. Xu, Q. Xu, W. H. Ge, Analysis of The Structural Parameters of Intake Uniform Board Impacting on The Airflow Distribution In The Bag Filter, Environ. Eng. 30 (2012) 76-80, doi: http:// lib.cqvip.com/qk/93897X/201204/42986782.html.

12. L. X. Ge, S. B. Lv, F. Zhang, Numerical Simulation and Calculation of the Inner Flow Field Based on the Filter Bag, J. Bengbu. Coll. 2 (2013) 22-25, doi: http://lib.cqvip.com/ qk/71567X/201303/46053146.html.

13. J. Han, B. L. Kong, X. H. Lv, Study on changes of hydrolysis degree and solution viscosity of HPAM at different reservoir temperatures, Oilfield Chem. 23 (2006) 235-238, doi: http://dx.doi.org/10.3969/j.issn.1000-4092.2006.03.011. 


\title{
SAŽETAK
}

\section{Tok matične otopine hidroliziranog poliakrilamida kroz filtarsku vrećicu:} određivanje učinka formulacije i parametara procesa na pad tlaka

\author{
Zi-Ming Feng, ${ }^{*}$ Xin Fang i Huan-Huan Ding
}

Matična otopina hidroliziranog poliakrilamida (HPAM) primjenjuje se u proizvodnji nafte. Prije ubrizgavanja u bušotinu otopina se pročišćava filtracijom kroz filtarsku vrećicu. Budući da pad tlaka matične otopine HPAM mora biti manji od 0,02 MPa, potrebno je istražiti parametre koji utječu na pad tlaka. Za određivanje utjecaja ključnih čimbenika na pad tlaka, kao što su poroznost, izlazni tlak filtrata, ulazni protok i viskoznost matične otopine, primijenjena računalna dinamika fluida (CFD). Simulacija pokazuje da se izlazni tlak nakon protjecanja kroz filtar raste s povećanjem poroznosti, izlaznog tlaka, ulaznog protoka i viskoznosti matične otopine.

\section{Ključne riječi}

Matična otopina hidroliziranog poliakrilamida, filtarska vrećica, pad tlaka, poroznost, viskoznost

School of Mechanical Science and Engineering

Stručni rad

Northeast Petroleum University,

163318 Daqing, Prispjelo 9. listopada 2014.
Prihvaćeno 16. ožujka 2015.

Kina 